\title{
$12: 12761576-12766570$
}

National Cancer Institute

\section{Source}

National Cancer Institute. 12:12761576-12766570. NCI Thesaurus. Code C41937.

Physical location of CDKN1B_Gene 